\title{
Patterns of Hydroxyurea Prescription and Use in Routine Clinical Management of Polycythemia Vera: A Multicenter Chart Review Study
}

\author{
Polistemia Vera'nın Rutin Yönetiminde Hidroksiüre Reçete Etme ve Kullanma Şekilleri: Çok \\ Merkezli Kayıt Tarama Çalışması
}

\begin{abstract}
(D) Yahya Büyükaşık1, (D) Rıdvan Ali2, (D) Mehmet Turgut ${ }^{3}$, (D) Güray Saydam4, (D) Akif Selim Yavuz5, (D) Ali Ünal6, (D) Muhlis Cem Ar7, (1) Orhan Ayyıldız8, (D) Fevzi Altuntaş9,10, (D) Müfide Okay1, (1) Rafiye Çiftçiler ${ }^{1}$, (D) Özgür Meletli3, (D) Nur Soyer ${ }^{4}$, (D) Metban Mastanzade5, (D) Zeynep Güven6, (D) Teoman Soysal7, (D) Abdullah Karakuş8, (D) Tuğçe Nur Yiğenoğlu10, (D) Barış Uçar11, (D) Ece Gökçen 11, (D) Tülin Tuğlular12

${ }_{1}^{1}$ Hacettepe University Faculty of Medicine, Department of Internal Medicine, Division of Hematology, Ankara, Turkey

2Uludağ University Faculty of Medicine, Department of Internal Medicine, Division of Hematology, Bursa, Turkey

3 Ondokuz Mayıs University Faculty of Medicine, Department of Internal Medicine, Division of Hematology, Samsun, Turkey

${ }^{4}$ Ege University Faculty of Medicine, Department of Internal Medicine, Division of Hematology, Izmir, Turkey

5istanbul University, Istanbul Faculty of Medicine, Department of Internal Medicine, Division of Hematology, Istanbul, Turkey

6Erciyes University Faculty of Medicine, Department of Internal Medicine, Division of Hematology, Kayseri, Turkey

7istanbul University-Cerrahpaşa, Cerrahpaşa Faculty of Medicine, Department of Internal Medicine, Division of Hematology, Istanbul, Turkey

${ }^{8}$ Dicle University Faculty of Medicine, Department of Internal Medicine, Division of Hematology, Diyarbakır, Turkey

${ }_{9}^{Y}$ YIdırım Beyazıt University Faculty of Medicine, Department of Internal Medicine, Division of Hematology, Ankara, Turkey

${ }^{10}$ Dr. Abdurrahman Yurtaslan Ankara Oncology Training and Research Hospital, Division of Hematology, Ankara, Turkey

${ }^{11}$ Novartis Oncology, Istanbul, Turkey

12 Marmara University Faculty of Medicine, Department of Internal Medicine, Division of Hematology, istanbul, Turkey
\end{abstract}

\section{Abstract}

Objective: This study aimed to evaluate real-life data on patterns of hydroxyurea prescription/use in polycythemia vera (PV).

Materials and Methods: This retrospective chart review study included PV patients who had received hydroxyurea therapy for at least 2 months after PV diagnosis. Data were collected from 10 representative academic medical centers.

Results: Of 657 patients, 50.9\% were in the high-risk group (age $\geq 60$ years and/or history of thromboembolic event). The median duration of hydroxyurea therapy was 43.40 months for all patients; $70.2 \%$ of the patients had ongoing hydroxyurea therapy at last followup. Hydroxyurea was discontinued in $22.4 \%$ of the patients; the most common reason was death $(38.5 \%)$. The predicted time until hydroxyurea discontinuation was 187.8 months (standard error: \pm 21.7 ) for all patients. This duration was shorter in females $(140.3 \pm 37.7$ vs. $187.8 \pm 29.7)(p=0.08)$. This trend was also observed in surviving patients aged $\geq 50$ years at hydroxyurea initiation $(122.2 \pm 12.4$ vs. $187.8 \pm 30.7$,
IIII

Öz

Amaç: Polistemia vera'da (PV) hidroksiüre reçete etme/kullanma şekilleri hakkındaki gerçek yaşam verilerini değerlendirmek.

Gereç ve Yöntemler: Bu retrospektif kayıt çalışmasına tanıdan sonra en az 2 ay hidroksiüre almış olan hastalar dahil edildi. Veriler ülkeyi temsil ettiği düşünülen 10 akademik tıp merkezinden toplandı.

Bulgular: Altı yüz elli yedi hastadan \%50,9'u yüksek risk (yaş $\geq 60$ yıl ve/veya tromboembolik olay öyküsü) grubundaydı. Tüm hastalarda ortanca hidroksiüre tedavi süresi 43,4 aydı. Hastaların \%70,2'si son kontrol tarihlerinde halen hidroksiüre kullanmaktaydı. Hidroksiüre en sık neden $(\% 38,5)$ ölüm olmak üzere hastaların $\% 22,4$ 'ünde kesilmişti. Tüm hasta grubunda hidroksiüre kesmek için ortanca süre 187,8 ay $\pm 21,7$ standart hata olarak hesaplandı. Bu süre kadınlarda $(140,3 \pm 37,7)$ erkeklere $(187,8 \pm 29,7)$ göre daha kısa idi $(p=0,08)$. $\mathrm{Bu}$ eğilim hidroksiüre başlandığında 50 yaş ve üstünde olan ve son durumda hayatta olan hastalarda da gözlendi $(122,2 \pm 12,4$ ve 


\section{Abstract}

$p=0.03)$. Among the patients who were still on hydroxyurea therapy, $40.3 \%$ had a hematocrit concentration of $\geq 45 \%$ at their last followup visit, and the rate of patients with at least one elevated blood cell count was $67.8 \%$.

Conclusion: Hydroxyurea prescription patterns and treatment aims are frequently not in accordance with the guideline recommendations. Its discontinuation rate is higher in females.

Keywords: Polycythemia vera, Hydroxyurea, Treatment outcome
$\ddot{\mathrm{O} z}$

$187,8 \pm 30,7, p=0,03)$. Hidroksiüre devam etmekte olan hastalarda son kontrolde $\geq 045$ hematokrit \%40,3 ve en az bir artmış kan hücre düzeyi \%67,8 oranında gözlendi.

Sonuç: Hidroksiüre reçete etme şekli ve tedavi hedefleri sıklıkla rehber önerilerine uymamaktadır. Hidroksiüre kesme oranı kadınlarda daha yüksektir.

Anahtar Sözcükler: Polistemia vera, Hidroksiüre, Tedavi sonucu

\section{Introduction}

Polycythemia vera (PV) is a Philadelphia chromosome-negative chronic myeloproliferative neoplasm. The incidence of PV has been estimated as 0.4-2.8 per 100,000/year in Europe and 0.8-1.3 in the United States [1]. The V617F mutation of the Janus kinase 2 (JAK2) gene on the $9^{\text {th }}$ chromosome is found in 95\%-97\% of PV patients and this discovery was a milestone in its diagnosis and treatment $[2,3]$. In many PV patients, the diagnosis can be overlooked for a long time and the disease may only be recognized after a thromboembolic event. Arterial and venous thromboses have been known as the major causes of morbidity and mortality in PV patients [2]. PV patients with advanced age ( $\geq 60$ years) and/or with a history of a thrombotic event are defined as having high thromboembolic risk [4].

The primary goals of PV treatment are to relieve symptoms, to prevent thromboembolic complications without increasing the risk of bleeding, and to minimize the risks of leukemia and myelofibrosis as secondary events [2,5]. Current recommendations for initial treatment include phlebotomy and low-dose acetylsalicylic acid. Cytoreduction (generally hydroxyurea or interferon-alpha in standard or PEGylated forms) is also required in patients with high thromboembolic risk, in those intolerant to phlebotomy, and in those with disease-related symptoms refractory to palliative drugs and interventions. Second-line treatment (standard/PEGylated interferon-alpha or JAK inhibitor ruxolitinib) should be considered for patients with hydroxyurea resistance/intolerance $[6,7]$.

Hydroxyurea has been used for the treatment of PV for nearly 40 years. Hydroxyurea therapy has been shown to decrease thrombotic event rates and leukemic transformation in PV patients $[4,8]$. It is the usual first-line treatment choice for cytoreduction based on long-term experience; moreover, it has the advantages of being an oral medication and having low treatment cost. On the other hand, there are also conflicting small studies reporting the increased risk of secondary solid cancer in patients with myeloproliferative neoplasms receiving hydroxyurea. Moreover, infertility and teratogenicity risks related to hydroxyurea should also be considered in young PV patients [8]. During recent years, the treatment aims of PV and the definitions of hydroxyurea resistance and intolerance have been clearly documented $[9,10]$. However, the impact of these developments on routine PV care has not been sufficiently documented. Thus, more data are required to show the patterns of hydroxyurea treatment of PV patients in daily practice and also the impact of these patterns on the treatment outcomes. This retrospective multicenter study aimed to evaluate real-life data on the patterns of hydroxyurea prescription and use in PV patients in Turkey.

\section{Materials and Methods}

\section{Patients}

This study included PV patients who were $\geq 18$ years of age at the time of PV diagnosis and who either were currently on hydroxyurea therapy for at least 2 months or had received hydroxyurea therapy at least 2 months after PV diagnosis. Patients who were included in any other clinical trial for PV were excluded.

\section{Study Design}

The present study, which was planned as a retrospective, descriptive, non-randomized study, involved the review of patient charts obtained from hematologists working in 10 study centers. The recruiting centers were selected from provinces with populations that were chosen as representative of the population of the relevant geographic region of Turkey. Although no formal sample size calculation was performed in the present study, the number of patients to be enrolled in each province was calculated based on the overall population and a maximum of 700 patients were expected to be enrolled. The patient charts were reviewed by the local investigators receiving assistance from a sponsored contract research organization (CRO). Statistical analyses were done by the principal author and a CRO statistician. The manuscript was written by the principal author and a CRO medical writer. All authors had rights to access the data and the final manuscript was sent to them. The study was sponsored by Novartis Pharmaceuticals Corporation. The study protocol was reviewed and approved by the Ethics 
Board of Hacettepe University.

\section{Procedure}

The patient charts were reviewed retrospectively starting from the chart of the most recently examined patient and the ones fulfilling the selection criteria were included in the study. Data collection was performed through the transfer of the data from the patient charts to hard-copy data collection forms and then to electronic tables. Patients' data regarding demographics, medical history, history of $\mathrm{PV}$, presence of the JAK2V617F mutation, thrombosis and bleeding history, information on cytoreductive therapy, and findings of routine laboratory tests were collected from the charts.

\section{Definitions}

Upfront treatment with hydroxyurea was arbitrarily defined as initiation of the drug within 2 months of diagnosis. Highrisk disease was defined as age of $\geq 60$ years and/or history of a thrombotic event [4].

Hydroxyurea resistance/intolerance was defined according to the European LeukemiaNet (ELN) criteria as follows: i) need for phlebotomy to keep the hematocrit concentration at $<45 \%$ after hydroxyurea therapy used for at least 3 months at a dose of $\geq 2 \mathrm{~g} /$ day, or ii) uncontrolled myeloproliferation (platelet count of $>400 \times 10^{9} / \mathrm{L}$ and white blood cell [WBC] count of $>10 \times 10^{9} / \mathrm{L}$ ) after hydroxyurea therapy used for at least 3 months at a dose of $\geq 2 \mathrm{~g} /$ day, or iii) failure to reduce massive splenomegaly ( $>10$ $\mathrm{cm}$ underneath the rib) by at least $50 \%$ on palpation or failure to completely improve splenomegaly-related symptoms after hydroxyurea therapy used for at least 3 months at a dose of $\geq 2 \mathrm{~g} /$ day, or iv) an absolute neutrophil count of $<1 \times 10^{9} / \mathrm{L}$ or a platelet count of $<100 \times 10^{9} / \mathrm{L}$ or a hemoglobin level of $<10 \mathrm{~g} / \mathrm{dL}$ at the lowest hydroxyurea dose required to provide complete or partial clinicohematological response as defined by the ELN [9], or v) the presence of leg ulcers or other unacceptable hydroxyureaassociated nonhematological toxicities (mucocutaneous signs, gastrointestinal symptoms, pneumonia, or fever) [10].

\section{Statistical Analyses}

Data analysis was performed using IBM SPSS Statistics for Windows, Version 23.0 (IBM Corp., Armonk, NY, USA). Descriptive statistics were expressed as numbers and percentages for categorical variables and as mean \pm standard deviation or median (standard error [SE]) (range or interquartile range) for numerical variables. Normality of data was tested using visual (histograms, probability plots) and analytical methods (Kolmogorov-Smirnov/ Shapiro-Wilk tests). The chi-square test was used to compare independent categorical variables, whereas Student's t-test was used to compare numerical variables. The continuation rate of hydroxyurea was calculated as a ratio and also using Kaplan-
Meier analysis. Values of $p<0.05$ were considered as statistically significant.

\section{Results}

Charts of 657 PV patients who were diagnosed between January 1985 and July 2017 were reviewed until April 2018. Fifty-one patients not receiving hydroxyurea and 18 patients not fulfilling the criteria of the study protocol were excluded; accordingly, data of 588 patients were included in the statistical analyses. Of the patients, 56.8\% were male, 44.9\% were aged $\geq 60$ years, $89.2 \%$ of the tested cases were positive for the JAK2V617F mutation, and $8.2 \%$ had an active or a history of a thromboembolic/vascular event at diagnosis. Of the patients, $50.9 \%(295 / 579)$ were in the high-risk group (age $\geq 60$ years and/or history of a thrombotic event) at diagnosis. The general characteristics of the study patients and hydroxyurea therapy are presented in Tables 1 and 2, respectively.

All PV patients $(n=588)$ received hydroxyurea therapy, while $1.7 \%, 2.4 \%$, and $3.9 \%$ of the patients respectively received standard or PEGylated recombinant interferon alpha, or anagrelide as a second cytoreductive therapy in addition to hydroxyurea therapy (Table 2). It was observed that the most common initial hydroxyurea dosage was $500 \mathrm{mg}$ BID (41\%), followed by $500 \mathrm{mg}$ OD (33.5\%). Of the patients, 70.7\% were observed to require at least one dose adjustment after initial dosing (Table 2).

Evaluation of the patients for whom the exact starting date of hydroxyurea treatment was known $(n=496)$ revealed that there were 284 (57.3\%) patients who were commenced on hydroxyurea therapy within the first 2 months after the diagnosis, whereas $212(42.7 \%)$ patients started hydroxyurea later (at a median of 20.3 months [interquartile range: 7.1-49.5 months] after the diagnosis). The characteristics of the patients according to their hydroxyurea therapy schedule (i.e. upfront or later) are presented in Table 3.

High-risk patients were more frequently commenced on upfront therapy with hydroxyurea; the rates were $63 \%$ in the age group of $\geq 60$ years $(n=260)$ and $52.5 \%$ in the age group of $<60$ years $(n=319)(p=0.019)$, and the rates were $72.3 \%$ in the patients with thrombotic/vascular event $(n=54)$ and $55.6 \%$ in those without $(n=523)(p=0.028)$. In addition, a WBC count of $>15 \times 10^{9} / L$ was also associated with commencement of upfront hydroxyurea (the rates were $74 \%$ in those with a WBC count of $>15 \times 10^{9} / \mathrm{L}$ and $56.1 \%$ in those without; $p=0.002$ ).

The median duration of hydroxyurea therapy was 43.4 months (range: 2-378 months) for all patients. The number of patients who were still on hydroxyurea therapy at their last follow-up visit accounted for $70.2 \%(n=413)$ of the study population, whereas the number of those who discontinued hydroxyurea accounted for $22.4 \%(n=132)$. Excluding 43 cases with missing 


\begin{tabular}{|c|c|c|}
\hline Characteristics & $\mathbf{n}$ & \\
\hline Gender & 588 & \\
\hline Male & & $334(56.8 \%)$ \\
\hline Female & & $254(43.2 \%)$ \\
\hline Age, years & 579 & $58(21-86)$ \\
\hline$<60$ & & $319(55.1 \%)$ \\
\hline$\geq 60$ & & $260(44.9 \%)$ \\
\hline Smoking status & 322 & \\
\hline Never smoked & & $222(66.1 \%)$ \\
\hline Former smoker & & $56(18.1 \%)$ \\
\hline Current smoker & & $44(15.8 \%)$ \\
\hline $\begin{array}{l}\text { Presence/history of } \\
\text { thrombotic/vascular event at } \\
\text { diagnosis* }^{*}\end{array}$ & 588 & $48(8.2 \%)$ \\
\hline Comorbidities at diagnosis & 588 & \\
\hline Hypertension & & $196(33.3 \%)$ \\
\hline Diabetes mellitus & & $70(11.9 \%)$ \\
\hline Cardiovascular disease & & $42(7.1 \%)$ \\
\hline JAK2V617F positivity & 579 & \\
\hline Yes & & $440(76.0 \%)$ \\
\hline No & & $53(9.2 \%)$ \\
\hline Unknown & & $86(14.9 \%)$ \\
\hline \multicolumn{3}{|c|}{ Mean complete blood count values at the start of treatment } \\
\hline Hematocrit, \% & 458 & $48.8 \pm 7.3$ \\
\hline White blood cells, $\times 10^{9} / \mathrm{L}$ & 458 & $14.2 \pm 16.0$ \\
\hline Platelets, $\times 10^{9} / \mathrm{L}$ & 465 & $521.0 \pm 319.8$ \\
\hline $\begin{array}{l}\text { Median disease duration, } \\
\text { months }\end{array}$ & 568 & $64.9(3-392)$ \\
\hline
\end{tabular}

data, the discontinuation rate for hydroxyurea therapy was $24.2 \%$. The median duration of hydroxyurea therapy was 36.4 months (range: 2-378 months) for the patients who discontinued hydroxyurea therapy and 45.8 months (range: 2-323 months) for those who continued.

The reported reasons for discontinuation of hydroxyurea therapy were death (38.5\%), toxicity (33.3\%), inappropriate disease control or disease progression (22.8\%), and other/ unknown (5.4\%). The patients who discontinued and those who were continuing hydroxyurea treatment were compared according to their demographic/clinical variables. Gender was
Table 2. General characteristics of hydroxyurea therapy.

\begin{tabular}{|c|c|c|}
\hline Characteristics & $\mathbf{n}$ & \\
\hline $\begin{array}{l}\text { Median (range) duration of } \\
\text { hydroxyurea therapy, months }\end{array}$ & 588 & $43.4(2-378)$ \\
\hline $\begin{array}{l}\text { Drugs used in addition to } \\
\text { hydroxyurea }\end{array}$ & 588 & \\
\hline Acetylsalicylic acid & & $454(77.2 \%)$ \\
\hline Warfarin & & $40(6.8 \%)$ \\
\hline Anagrelide & & $23(3.9 \%)$ \\
\hline $\begin{array}{l}\text { PEGylated recombinant interferon } \\
\text { alpha }\end{array}$ & & $14(2.4 \%)$ \\
\hline JAK inhibitors & & $11(1.9 \%)$ \\
\hline $\begin{array}{l}\text { Standard recombinant interferon } \\
\text { alpha }\end{array}$ & & $10(1.7 \%)$ \\
\hline Clopidogrel & & $7(1.2 \%)$ \\
\hline Other medications & & $114(19.4 \%)$ \\
\hline Initial hydroxyurea dosages & 588 & \\
\hline $500 \mathrm{mg} \mathrm{BID}$ & & $241(41.0 \%)$ \\
\hline $500 \mathrm{mg}$ QD & & $197(33.5 \%)$ \\
\hline $500 \mathrm{mg}$ TID & & $66(11.2 \%)$ \\
\hline Other & & $84(14.3 \%)$ \\
\hline Highest total dose during follow-up & 385 & \\
\hline $500 \mathrm{mg}$ & & $12(3.1 \%)$ \\
\hline $1000 \mathrm{mg}$ & & $147(38.2 \%)$ \\
\hline $1500 \mathrm{mg}$ & & $147(38.2 \%)$ \\
\hline $2000 \mathrm{mg}$ & & $56(14.5 \%)$ \\
\hline $3000 \mathrm{mg}$ & & $19(4.9 \%)$ \\
\hline $4000 \mathrm{mg}$ & & $3(0.8 \%)$ \\
\hline $2500 \mathrm{mg}$ & & $1(0.3 \%)$ \\
\hline $\begin{array}{l}\text { Number of dose changes during } \\
\text { hydroxyurea therapy }\end{array}$ & 588 & \\
\hline None & & $172(29.3 \%)$ \\
\hline 1 & & $100(17.0 \%)$ \\
\hline 2 & & $64(10.9 \%)$ \\
\hline 3 & & $45(7.7 \%)$ \\
\hline 4 & & $37(6.3 \%)$ \\
\hline 5 & & $25(4.3 \%)$ \\
\hline$>5$ & & $145(24.7 \%)$ \\
\hline
\end{tabular}




\begin{tabular}{|c|c|c|c|c|}
\hline & \multirow[b]{2}{*}{$\mathrm{n}$} & \multicolumn{2}{|c|}{ Hydroxyurea therapy schedule } & \multirow{2}{*}{$\mathbf{p}$} \\
\hline & & Upfront & Later & \\
\hline Age, years & & n $(\%)$ & n $(\%)$ & \\
\hline$<60$ & 274 & $144(52.5)$ & $130(47.5)$ & \multirow{2}{*}{0.019} \\
\hline$\geq 60$ & 222 & $140(63.0)$ & $82(37.0)$ & \\
\hline \multicolumn{5}{|c|}{ History of thrombotic/vascular event } \\
\hline Yes & 47 & $34(72.3)$ & $13(27.7)$ & \multirow{2}{*}{0.028} \\
\hline No & 449 & $250(55.6)$ & $199(44.4)$ & \\
\hline \multicolumn{5}{|c|}{ Diabetes mellitus } \\
\hline Yes & 57 & $27(47.3)$ & $30(52.7)$ & \multirow{2}{*}{0.079} \\
\hline No & 411 & $245(59.6)$ & $166(40.4)$ & \\
\hline \multicolumn{5}{|c|}{ Hypertension } \\
\hline Yes & 158 & $87(45.0)$ & $71(55.0)$ & \multirow{2}{*}{0.449} \\
\hline No & 322 & $189(58.7)$ & $133(41.3)$ & \\
\hline \multicolumn{5}{|c|}{ White blood cells $>15 \times 10^{9} / \mathrm{L}$} \\
\hline Yes & 100 & $74(74.0)$ & $26(26.0)$ & \multirow{2}{*}{0.002} \\
\hline No & 308 & $173(56.1)$ & $135(43.9)$ & \\
\hline \multicolumn{5}{|c|}{ Platelets $>1000 \times 10^{9} / \mathrm{L}$} \\
\hline Yes & 28 & $21(75.0)$ & $7(25.0)$ & \multirow{2}{*}{0.09} \\
\hline No & 386 & $227(58.8)$ & $159(41.2)$ & \\
\hline
\end{tabular}

\begin{tabular}{|c|c|c|c|c|}
\hline & & Hydroxyurea $t$ & & \\
\hline & & Discontinued & Continuing & p \\
\hline & $\mathbf{n}$ & n (\%) & n (\%) & \\
\hline Gender & & & & \\
\hline Male & 307 & 50 (16.3) & 257 (83.7) & רחח \\
\hline Female & 238 & 65 (27.3) & 173 (72.7) & 0.002 \\
\hline Age, yea & & & & \\
\hline$<60$ & 294 & $65(22.1)$ & 229 (77.9) & 0446 \\
\hline$\geq 60$ & 247 & 48 (19.4) & 199 (80.6) & 0.440 \\
\hline Hyperte & & & & \\
\hline Yes & 176 & $36(20.5)$ & 140 (79.5) & 0642 \\
\hline No & 351 & $78(22.2)$ & 273 (77.8) & 0.072 \\
\hline Diabetes & & & & \\
\hline Yes & 65 & 9 (13.8) & 56 (86.2) & 0120 \\
\hline No & 449 & $100(22.3)$ & 349 (77.7) & 0.120 \\
\hline Thrombc & & & & \\
\hline Yes & 69 & $18(26.1)$ & 51 (73.9) & 0699 \\
\hline No & 476 & 114 (23.9) & 362 (76.1) & 0.000 \\
\hline Hemorrh & & & & \\
\hline Yes & 13 & $3(23.1)$ & 10 (76.9) & 0847 \\
\hline No & 508 & 106 (20.9) & 402 (79.1) & תד.0 \\
\hline
\end{tabular}


determined as a significant variable for discontinuation; the rate of discontinuation was significantly higher in females than in males $(27.3 \%$ versus $16.3 \%, p=0.002)$ (Table 4$)$. Limiting the analysis to patients aged $\geq 50$ years, the rate of drug discontinuation was still higher among females $(27.3 \%$ vs. $10.2 \%, p<0.001)$.

According to the Kaplan-Meier analysis, the median time until hydroxyurea discontinuation was found as 187.8 months (SE: 21.7; range: 145.1-230.4 months) for all patients. This duration was shorter in females (140.3 months [SE: 37.7 months; range: $66.2-214.3$ months]) than in males (187.8 months [SE: 29.7; range: 129.5-246 months]) ( $p=0.08)$. We also limited the Kaplan-Meier analysis to surviving patients aged $\geq 50$ years at hydroxyurea initiation in order to understand if the main reasons for hydroxyurea discontinuation were fertility/ teratogenicity concerns or death. We found that the median time until hydroxyurea discontinuation was still significantly shorter in females (122.2 months [SE: 12.4; range: 97.8146.5 months] vs. 187.8 months [SE: 30.7 ; range: $127.5-248]$ ) $(p=0.03)$, indicating that the above-mentioned factors were not the main reasons for drug discontinuation (Figure 1).

Complete blood count values during the last follow-up visits of the patients still on hydroxyurea therapy are demonstrated in Table 5. Values indicating uncontrolled myeloproliferation were frequent, with rates of $40.3 \%, 29.2 \%, 34.4 \%$, and $67.8 \%$ for elevated hematocrit $(\geq 45 \%)$, platelet count $\left(>400 \times 10^{9} / \mathrm{L}\right), \mathrm{WBC}$ count $\left(>10 \times 10^{9} / \mathrm{L}\right)$, and at least one of these three. The rates of hydroxyurea resistance (7.9\%) and intolerance (8.1\%) were

\begin{tabular}{|l|l|}
\hline $\begin{array}{l}\text { Table 5. Complete blood count values during the last follow- } \\
\text { up visits of the patients who were still on hydroxyurea } \\
\text { therapy. }\end{array}$ \\
\hline Hematocrit, $\%$ & $\%$ \\
\hline$\geq 45$ & 40.3 \\
\hline$<45$ & 59.7 \\
\hline Platelets, $\times 10^{9} / \mathrm{L}$ & \\
\hline$\geq 400$ & 29.2 \\
\hline$<400$ & 70.8 \\
\hline White blood cells, $\times 10^{9} / \mathrm{L}$ & \\
\hline$\geq 10$ & 34.4 \\
\hline$<10$ & 65.6 \\
\hline At least one of them elevated & \\
\hline Yes & 67.8 \\
\hline No & 32.2 \\
\hline $\begin{array}{l}\text { Uncontrolled myeloproliferation in the ELN } \\
\text { definition of hydroxyurea resistance* }\end{array}$ & \\
\hline Yes & 47.8 \\
\hline No & 52.2 \\
\hline $\begin{array}{l}* \text { Hematocrit } \geq 45 \% \text { and } / \text { or platelets }>400 \times 10^{9} / L \text { and white blood cells }>10 \times 10^{\circ} / L . \\
\text { ELN, European LeukemiaNet. }\end{array}$ \\
\hline
\end{tabular}

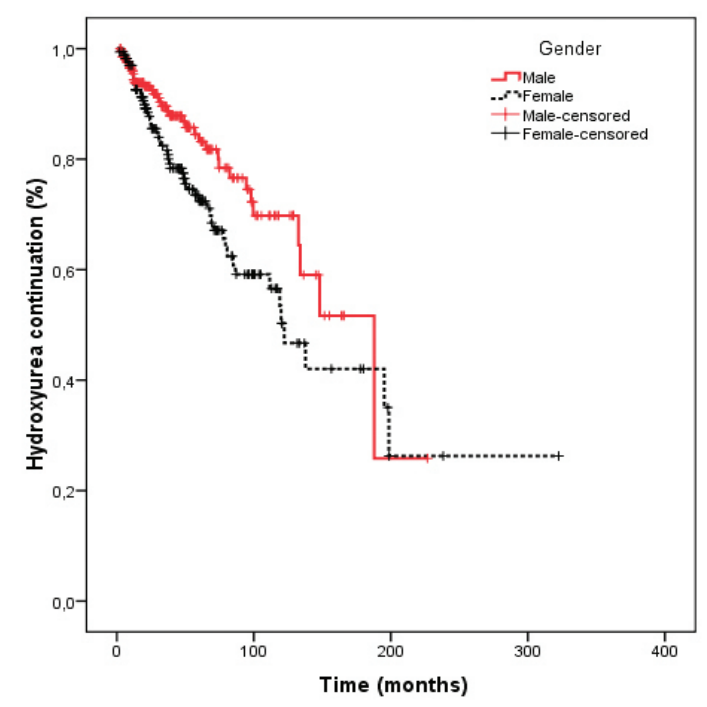

Figure 1. Kaplan-Meier analysis for continuation rate of hydroxyurea according to gender in surviving patients of $\geq 50$ years of age.

estimated as $16 \%$ in total.

While the frequencies of thrombotic/vascular events, hemorrhage, and solid tumor at diagnosis were 8.2\%, 2.2\%, and $1.5 \%$, respectively, they were $4.8 \%, 0 \%$, and $0.17 \%$ under hydroxyurea therapy. Secondary myeloid neoplasms (i.e. acute myeloid leukemia or myelodysplastic syndrome) and post-PV myelofibrosis during hydroxyurea treatment were reported in 3 and 7 cases, respectively. The estimated risks at 10 years were $6.2 \%$ and $8 \%$.

\section{Discussion}

Hydroxyurea remains the first-line cytoreductive therapy in the treatment of patients with PV [11]. The present research was designed as a multicenter chart review study to evaluate the patterns of hydroxyurea prescription/use in PV patients in Turkey. Evaluation of real-life data is beneficial in order to obtain more information about patterns of therapy use, compliance with the guidelines, treatment outcomes, and reasons for failure and to establish strategies for improving therapeutic approaches.

$\mathrm{PV}$ is more prevalent in the elderly population and advanced age ( $\geq 60$ years) is a significant risk factor for prognosis and survival. In our study, nearly half of the patients (44.9\%) were $\geq 60$ years. In a chart review study from Germany, 1476 PV patients were evaluated and $77.1 \%$ were found to be over the age of 60 years [12]. In a cross-sectional survey from Belgium, 343 PV patients were evaluated and $74.6 \%$ of them were $\geq 60$ years of age [13]. Our cohort was relatively younger (median: 58 years), possibly due to the demographic characteristics of Turkey.

In their international study, Tefferi et al. [14] evaluated 1545 PV 
patients and reported advanced age and a leukocyte count of $>15 \times 10^{9} / \mathrm{L}$ as the risk factors for poor prognosis. The classical risk factors for thrombotic events in PV patients include age of $\geq 60$ years, history of thrombosis, and a hematocrit concentration of $\geq 45 \%$. In addition, other risk factors still in need of validation have been reported, such as an elevated WBC count, female gender, mutant JAK2 allele burden, and classical cardiovascular risk factors [15]. In the present study, 50.9\% of the patients were in the high-risk group (age $\geq 60$ years and/or history of a thrombotic event).

Analysis of the JAK2 mutation is an important criterion for the diagnosis of PV. In a prospective observational study from the United States, nearly half of the patients $(n=2510)$ were investigated for the presence of JAK2 mutation and 95.8\% of these patients were found to be positive for JAK2V617F mutation [16]. In the present study, the JAK2V617F mutation was positive in $89.2 \%$ of the tested patients. The mutation status was unknown in $14.9 \%$ of the patients. These cases were mostly diagnosed before discovery of the mutation. JentschUllrich et al. [12] reported the mutation status as unknown in $23 \%$ of their patients, which was also attributed to the fact that the diagnoses were established before the molecular analysis became a routine part of the diagnosis. The JAK2 mutation was included in the diagnostic criteria in the revised 2008 WHO classification system [17].

Although risk stratification of PV patients can be a guide for treatment, the patients may still be subjected to the risk of overtreatment or undertreatment [18]. A study evaluating reallife data demonstrated that cytoreductive drugs were not used in the majority of patients having an indication for cytoreductive therapy, also including high-risk patients [19]. Similarly, many of the high-risk patients in our cohort did not receive upfront therapy with hydroxyurea.

Patients with PV are at higher risk of morbidity and mortality as compared with the general population. Thrombotic and hemorrhagic events are the major complications associated with mortality [15]. Treatment focuses on prevention of these complications. It has been reported that patients treated with hydroxyurea had fewer vascular events as compared with those treated by phlebotomy alone [20]. Barbui et al. [21] compared hydroxyurea therapy with phlebotomy in PV patients and reported fewer cardiovascular events and hematological transformations (myelofibrosis transformation and acute leukemic transformation) as well as decreased overall mortality in those using hydroxyurea. In the present study, while the frequency of thrombotic/vascular event history at diagnosis was $8.2 \%$, it was found to be $4.8 \%$ under hydroxyurea therapy.

Parasuraman et al. [22] reported that hydroxyurea was discontinued in $17.5 \%$ of their patients, mostly because of inadequate response (29.3\%), intolerance (27.5\%), and disease progression (12.7\%). They also determined elevated blood cell counts (hematocrit concentration of $\geq 45 \%$, platelet count of $>400 \times 10^{9} / \mathrm{L}$, WBC count of $>10 \times 10^{9} / \mathrm{L}$ ) in significant proportions of their patients on hydroxyurea $(34.4 \%, 59.4 \%$, and $58.2 \%$, respectively). Similar outcomes were also obtained in the present study; hydroxyurea was discontinued in $22.4 \%$ of the patients and the main reported reasons for discontinuation were death $(38.5 \%)$, toxicity $(33.3 \%)$, and inappropriate disease control or progression $(22.8 \%)$. Of the patients who were still on hydroxyurea therapy, $40.3 \%$ had a hematocrit concentration of $\geq 45 \%, 29.2 \%$ had a platelet count of $>400 \times 10^{9} / \mathrm{L}$, and $34.4 \%$ had a WBC count of $>10 \times 10^{9} / \mathrm{L}$.

Resistance/intolerance has been reported in nearly one-fourth of the patients receiving hydroxyurea therapy $[15,23]$. Hydroxyurea resistance/intolerance in $\mathrm{PV}$ patients is associated not only with an increased mortality rate but also with increased healthcare costs [24]. A study from Spain reviewed the medical charts of patients diagnosed with PV in 5 centers $(n=261)$ and reported the frequencies of hydroxyurea resistance and intolerance as $11.5 \%$ and $12.6 \%$, respectively [25]. In a larger series from Spain $(n=890)$, the frequency of hydroxyurea resistance and/or intolerance was reported as 15\% [26]. The difference between these two studies was attributed to different follow-up periods of patients or different doses of hydroxyurea used in the centers [26]. In a cross-sectional study from Belgium, 12\% of the patients were reported to have hydroxyurea resistance/ intolerance [13]. This rate was found to be $16 \%$ in the present study. However, we should accept that limited retrospective data quality (particularly the ambiguity about the definition of massive splenomegaly and the data concerning duration of hydroxyurea used at a dose of $\geq 2 \mathrm{~g}$ ) might have obscured the exact figure. Among the patients who were still on hydroxyurea therapy in the present study, the rate of those with a hematocrit concentration of $\geq 45 \%$ at the last follow-up visit was $40.3 \%$, and the rate of patients in whom at least one of the hematocrit, platelet, or WBC values was high was $67.8 \%$. On the other hand, only $20.5 \%$ received $\geq 2 \mathrm{~g} /$ day hydroxyurea at any time during the disease course. This trend has not changed in recent years (data not shown). Accordingly, these data indicated that the ELN treatment response criteria [9] were not adequately considered and consequently hydroxyurea resistance was not routinely evaluated in clinical practice. Dose titration was not sufficiently considered despite elevated hematocrit concentration/blood count values under hydroxyurea therapy.

In the present study, discontinuation of hydroxyurea therapy was more common in females than in males $(27.3 \%$ vs. $16.3 \%$, $\mathrm{p}=0.002$ ). Limiting the analysis to the patients aged $\geq 50$ years, the drug discontinuation rate was still higher in females $(27.3 \%$ vs. $10.2 \%, p<0.001)$. For this reason, we think that the higher 
hydroxyurea discontinuation rate in females was not due to fertility and/or teratogenicity concerns. We assume that aesthetic concerns due to cutaneous side effects might be a potential reason for this difference.

\section{Conclusion}

The use of hydroxyurea for the treatment of PV in routine clinical practice is not in line with the guideline recommendations in some regards. Among hydroxyurea users, a substantial proportion of patients had blood count values that remained higher than recommended in the guidelines. These findings underline the need for more emphasis on the importance of reviewing treatment algorithms in accordance with the recommendations of current guidelines and following these algorithms in clinical practice. The finding of a higher hydroxyurea discontinuation rate among women and its reasons should be further investigated.

\section{Ethics}

Ethics Committee Approval: Hacettepe University, Faculty of Medicine, Ankara, Turkey, 05 December 2017, G0 17/916-06.

Informed Consent: Was not deemed necessary due to type of research.

\section{Authorship Contributions}

Surgical and Medical Practices: Y.B., R.A., M.T., G.S., A.S.Y., A.Ü., M.C.A., O.A., F.A., M.O., R.Ç., Ö.M., N.S., M.M., Z.G., T.S., A.K., T.N.Y, T.T.; Concept: Y.B., R.A., M.T., G.S., A.S.Y., A.Ü., M.C.A., O.A., F.A., T.S., T.T.; Design: Y.B., B.U., E.G.; Data Collection or Processing: Y.B., R.A., M.T., G.S., A.S.Y., A.Ü., M.C.A., O.A., F.A., M.O., R.Ç., Ö.M., N.S., M.M., Z.G., T.S., A.K., T.N.Y, T.T.; Analysis or Interpretation: Y.B.; Literature Search: Y.B.; Writing: Y.B.

Conflict of Interest: Y.B., R.A., M.T., G.S., A.S.Y., A.Ü., M.C.A., O.A., F.A., and T.T. received research grants from Novartis Pharmaceuticals Corporation paid to their institutions. B.U. and E.G. are employees of Novartis Pharmaceuticals Corporation.

Financial Disclosure: Y.B., R.A., M.T., G.S., A.S.Y., A.Ü., M.C.A., O.A., F.A., and T.T. received research grants from Novartis Pharmaceuticals Corporation paid to their institutions. B.U. and E.G. are employees of Novartis Pharmaceuticals Corporation.

\section{References}

1. Maffioli M, Mora B, Passamonti F. Polycythemia vera: from new, modified diagnostic criteria to new therapeutic approaches. Clin Adv Hematol Oncol 2017;15:700-707.

2. Spivak JL. Polycythemia vera. Curr Treat Options Oncol 2018;19:12.

3. Stein BL, Oh ST, Berenzon D, Hobbs GS, Kremyanskaya M, Rampal RK, Abboud CN, Adler K, Heaney ML, Jabbour EJ, Komrokji RS, Moliterno AR, Ritchie EK, Rice L, Mascarenhas J, Hoffman R. Polycythemia vera: an appraisal of the biology and management 10 years after the discovery of JAK2 V617F. J Clin Oncol 2015;33:3953-3960.
4. Tefferi A, Barbui T. Polycythemia vera and essential thrombocythemia: 2019 update on diagnosis, risk-stratification and management. Am J Hematol 2019;94:133-143.

5. Hatalova A, Schwarz J, Gotic M, Penka M, Hrubisko M, Kusec R, Egyed $M$, Griesshammer $M$, Podolak-Dawidziak $M$, Hellmann $A$, Klymenko $S$, Niculescu-Mizil E, Petrides PE, Grosicki S, Sever M, Cantoni N, Thiele J, Wolf $\mathrm{D}$, Gisslinger H. Recommendations for the diagnosis and treatment of patients with polycythaemia vera. Eur J Haematol 2018;101:654-664.

6. Mesa RA. New guidelines from the NCCN for polycythemia vera. Clin Adv Hematol Oncol 2017;15:848-850.

7. Barbui T, Tefferi A, Vannucchi AM, Passamonti $F$, Silver RT, Hoffman R, Verstovsek S, Mesa R, Kiladjian JJ, Hehlmann R, Reiter A, Cervantes $F_{1}$ Harrison C, Mc Mullin MF, Hasselbalch HC, Koschmieder S, Marchetti M, Bacigalupo A, Finazzi G, Kroeger N, Griesshammer M, Birgegard G, Barosi G. Philadelphia chromosome-negative classical myeloproliferative neoplasms: revised management recommendations from European LeukemiaNet. Leukemia 2018;32:1057-1069.

8. Buyukasik Y, Ali R, Ar C, Turgut M, Yavuz S, Saydam G. Polycythemia vera: diagnosis, clinical course, and current management. Turk J Med Sci 2018;48:698-710.

9. Barosi $G$, Mesa $R$, Finazzi $G$, Harrison $C$, Kiladjian JJ, Lengfelder $E$, McMullin MF, Passamonti F, Vannucchi AM, Besses C, Gisslinger $H$, Samuelsson J, Verstovsek S, Hoffman R, Pardanani A, Cervantes F, Tefferi A, Barbui T. Revised response criteria for polycythemia vera and essential thrombocythemia: an ELN and IWG-MRT consensus project. Blood 2013;121:4778-4781.

10. Barosi G, Birgegard G, Finazzi G, Griesshammer $M$, Harrison $C$, Hasselbalch $H$, Kiladijan JJ, Lengfelder E, Mesa R, Mc Mullin MF, Passamonti F, Reilly JT, Vannucchi AM, Barbui T. A unified definition of clinical resistance and intolerance to hydroxycarbamide in polycythaemia vera and primary myelofibrosis: results of a European LeukemiaNet (ELN) consensus process. Br J Haematol 2010;148:961-963.

11. Tefferi A, Vannucchi AM, Barbui T. Polycythemia vera treatment algorithm 2018. Blood Cancer J 2018;8:3.

12. Jentsch-Ullrich K, Eberhardt J, Zeremski V, Koehler M, Wolleschak D, Heidel $\mathrm{FH}$. Characteristics and treatment of polycythemia vera patients in clinical practice: a multicenter chart review on 1476 individuals in Germany. J Cancer Res Clin Oncol 2016;142:2041-2049.

13. Devos $T$, Beguin $Y$, Noens $L$, Van Eygen $K$, Zachée $P$, Mineur $P$, Knoops $L$, Doyen C, Theunissen K, Benghiat FS, Reusens M, Pluymers W. Disease and treatment characteristics of polycythemia vera patients in Belgium: results from a scientific survey. Eur J Haematol 2018;100:361-366.

14. Tefferi $A$, Rumi $E$, Finazzi $G$, Gisslinger $H$, Vannucchi $A M$, Rodeghiero $F$, Randi ML, Vaidya R, Cazzola M, Rambaldi A, Gisslinger B, Pieri L, Ruggeri M, Bertozzi I, Sulai NH, Casetti I, Carobbio A, Jeryczynski G, Larson DR, Müllauer L, Pardanani A, Thiele J, Passamonti F, Barbui T. Survival and prognosis among 1545 patients with contemporary polycythemia vera: an international study. Leukemia 2013;27:1874-1881.

15. Gerds AT, Dao KH. Polycythemia vera management and challenges in the community health setting. Oncology 2017;92:179-189.

16. Grunwald MR, Stein BL, Boccia RV, Oh ST, Paranagama D, Parasuraman S, Colucci P, Mesa R. Clinical and disease characteristics from REVEAL at time of enrollment (baseline): prospective observational study of patients with polycythemia vera in the United States. Clin Lymphoma Myeloma Leuk 2018;18:788-795.

17. Tefferi A, Thiele J, Vardiman JW. The 2008 World Health Organization classification system for myeloproliferative neoplasms: order out of chaos. Cancer 2009;115:3842-3847.

18. Sankar K, Stein BL. Do all patients with polycythemia vera or essential thrombocythemia need cytoreduction? J Natl Compr Canc Netw 2018;16:1539-1545. 
19. Paranagama D, Colucci P, Evans KA, Bonafede M, Parasuraman S. Are patients with high-risk polycythemia vera receiving cytoreductive medications? A retrospective analysis of real-world data. Exp Hematol Oncol 2018;7:16.

20. Enblom-Larsson A, Girodon F, Bak M, Hersby D, Jooste $V$, Hasselbalch $H$, Johansson $P$, Andreasson $B$. A retrospective analysis of the impact of treatments and blood counts on survival and the risk of vascular events during the course of polycythaemia vera. Br J Haematol 2017;177:800805.

21. Barbui T, Vannucchi AM, Finazzi G, Finazzi MC, Masciulli A, Carobbio A, Ghirardi A, Tognoni G. A reappraisal of the benefit-risk profile of hydroxyurea in polycythemia vera: a propensity-matched study. Am J Hematol 2017;92:1131-1136.

22. Parasuraman S, DiBonaventura M, Reith K, Naim A, Concialdi K, Sarlis NJ. Patterns of hydroxyurea use and clinical outcomes among patients with polycythemia vera in real-world clinical practice: a chart review. Exp Hematol Oncol 2016;5:3.

23. Nazha A, Khoury JD, Verstovsek S, Daver N. Second line therapies in polycythemia vera: What is the optimal strategy after hydroxyurea failure? Crit Rev Oncol Hematol 2016;105:112-117.
24. Parasuraman SV, Shi N, Paranagama DC, Bonafede M. Health care costs and thromboembolic events in hydroxyurea-treated patients with polycythemia vera. J Manag Care Spec Pharm 2018;24:47-55.

25. Alvarez-Larrán A, Pereira $A$, Cervantes $F$, Arellano-Rodrigo $E$, HernándezBoluda JC, Ferrer-Marín F, Angona A, Gómez M, Muiña B, Guillén H, Teruel A, Bellosillo B, Burgaleta C, Vicente V, Besses C. Assessment and prognostic value of the European LeukemiaNet criteria for clinicohematologic response, resistance, and intolerance to hydroxyurea in polycythemia vera. Blood 2012;119:1363-1369.

26. Alvarez-Larrán $A$, Kerguelen $A$, Hernández-Boluda JC, Pérez-Encinas $M$, Ferrer-Marín F, Bárez A, Martínez-López J, Cuevas B, Mata MI, GarcíaGutiérrez V, Aragües $P$, Montesdeoca $S$, Burgaleta C, Caballero G, Hernández-Rivas JA, Durán MA, Gómez-Casares MT, Besses C; Grupo Español de Enfermedades Mieloproliferativas Filadelfia Negativas (GEMFIN). Frequency and prognostic value of resistance/intolerance to hydroxycarbamide in 890 patients with polycythaemia vera. $\mathrm{Br} \mathrm{J}$ Haematol 2016;172:786-793. 